\title{
Influences of Leaf Area Index estimations on water balance modeling in a Mediterranean semi-arid basin
}

\author{
V. Gigante ${ }^{1}$, V. Iacobellis ${ }^{2}$, S. Manfreda ${ }^{3}$, P. Milella ${ }^{4}$, and I. Portoghese ${ }^{5}$ \\ ${ }^{1} \mathrm{COS}(\mathrm{OT})$ Consortium, University of Basilicata, Potenza, Italy \\ ${ }^{2}$ DIAC Department, Polytechnic University of Bari, Bari, Italy \\ ${ }^{3}$ DIFA Department, University of Basilicata, Potenza, Italy \\ ${ }^{4}$ PRO.GE.SA. Department, University of Bari, Bari, Italy \\ ${ }^{5}$ Water Research Institute, National Research Council of Italy, Bari, Italy
}

Received: 11 April 2008 - Revised: 25 March 2009 - Accepted: 25 May 2009 - Published: 25 June 2009

\begin{abstract}
In the present work, the role played by vegetation parameters, necessary to the hydrological distributed modeling, is investigated focusing on the correct use of remote sensing products for the evaluation of hydrological losses in the soil water balance. The research was carried out over a medium-sized river basin in Southern Italy, where the vegetation status is characterised through a data-set of multitemporal NDVI images. The model adopted uses one layer of vegetation whose status is defined by the Leaf Area Index (LAI), which is often obtained from NDVI images. The inherent problem is that the vegetation heterogeneity - including soil disturbances - has a large influence on the spectral bands and so the relation between LAI and NDVI is not unambiguous.

We present a rationale for the basin scale calibration of a non-linear NDVI-LAI regression, based on the comparison between NDVI values and literature LAI estimations of the vegetation cover in recognized landscape elements of the study catchment. Adopting a process-based model (DREAM) with a distributed parameterisation, the influence of different NDVI-LAI regression models on main features of water balance predictions is investigated. The results show a significant sensitivity of the hydrological losses and soil water regime to the alternative LAI estimations. These crucially affects the model performances especially in lowflows simulation and in the identification of the intermittent regime.
\end{abstract}

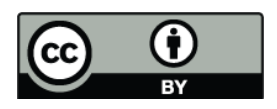

Correspondence to: P. Milella (pamelamilella@agr.uniba.it)

\section{Introduction}

Among prominent environmental hazards that occur in Mediterranean regions, floods and droughts may be considered the most dangerous for economic and social impact. Droughts may affect very large areas for months or years causing prolonged water stress for crops and forest trees, and affecting plant health and growth (Zierl, 2001). On the other hand flood prediction and mitigation is fundamental for economical and environmental wealth. In both cases, the development of knowledge in physical modeling is a crucial issue and spatially distributed hydrological models represent a useful platform accounting for processes that affect the vegetation state.

In a semi-arid Mediterranean environment, evapotranspiration is recognized as the main hydrologic loss $(50 \div 60 \%$ of mean annual rainfall) and can be evaluated as the sum of two distinct processes: evaporation from bare soil and transpiration from vegetative soil. In drought conditions, the evaporation from bare soil increases, while canopy transpiration generally decreases. Therefore, space-time distribution of vegetation is a key factor for a correct evaluation of evapotranspiration. This study is focused on the use of the Leaf Area Index (LAI) as a basic physiological descriptor of the vegetation cover. In particular, we used the Normalized Difference Vegetation Index (NDVI) derived from NOAA-AVHRR satellite data as an indicator of the vegetation status in the hydrologic modeling application. LAI maps may be derived from NDVI observations by means of several models available in literature. Among these we tested the simple equation proposed by Caraux-Garson et al. (1998) and the more complex Beer's law (Lacaze et al., 1996). Thus, the paper mainly focuses on the evaluation of the evapotranspiration fluxes in

Published by Copernicus Publications on behalf of the European Geosciences Union. 
water balance modeling and particular attention is devoted to the methodology for selecting and calibrating the most suitable LAI-NDVI relationship to be used at basin scale.

For this purpose, several hydrological models may be used for rainfall-runoff simulations and water balance analysis: TOPMODEL (Beven and Kirkby, 1979; Sivapalan et al., 1987), THALES (Grayson et al., 1995), TOPKAPI (Ciarapica and Todini, 2002), BROOK-90 model (Federer, 1995; Kennel, 1998), WaSiM-ETH model (Schulla, 1997; Gurtz et al., 1998), WAWAHAMO (Zierl, 2001) and many others. The selection of the "best" model always involves a balance between data requirements and cost of model implementation (Manfreda et al., 2005). For this paper, the semidistributed DREAM model (Manfreda et al., 2005) was selected to simulate the water balance in the study catchment. This model was chosen because (i) it has a parsimonious structure, (ii) it has proven to be suitable for the Mediterranean environment of Southern Italy (e.g., Fiorentino et al., 2007; Vita et al., 2008), (iii) following a rich and consistent literature it strongly exploits LAI information. Moreover, continuous simulations of D-DREAM (at daily timestep) can be used in prediction of both floods (providing the antecedent soil moisture conditions) and droughts. The same model has been used profitably in a number of works and applications such as those presented by Hyndman et al. (2007) and Sheikh et al. (2009).

The DREAM water balance simulation performance, evaluated with respect to daily flows recorded at a gauged site, is used to check the physical meaning and the numerical consistency of derived LAI vaues.

\section{The soil water balance in the DREAM}

DREAM (Distributed model for Runoff Et Antecedent soil Moisture simulation), introduced by Manfreda et al. (2005), is a semi-distributed hydrological model, suitable for continuous simulations. The main hydrological processes are computed on a grid-based representation of the river basin that takes into account the spatial heterogeneity of hydrological variables using digital elevation models, soil and vegetation grid-maps.

Canopy cover determines the amount of rainfall intercepted by vegetation before hitting the soil surface. Throughfall (precipitation minus interception) is initially stored in surface depressions; net precipitation (throughfall minus depression storage) is then subdivided in surface runoff and infiltration into the soil; soil water content, which is the limiting factor of evapotranspiration from vegetation, is redistributed within river sub-basins according to the morphological structure of the basin exploiting the wetness index proposed by Beven and Kirby (1979). Groundwater recharge is obtained as percolation through the vadose zone and is routed as a global linear reservoir.
DREAM applied at daily time-step requires the calibration of only one parameter, thanks to a robust and physically based parameterization, which allows for an extensive use of prior information. The DREAM model was applied in several medium-size basins, exhibiting considerable differences in climate and other physical characteristics (e.g., Manfreda et al., 2005; Fiorentino et al., 2007).

\subsection{Use of LAI in DREAM}

In the present section, the role of vegetation parameters in DREAM is described with particular reference to the basic equations where the LAI is taken into account.

The first hydrological loss of the model is represented by the canopy interception that may be responsible for losses reaching $10 \%-20 \%$ of the total precipitation on the annual scale (e.g. Chang, 2003). Therefore, a suitable representation of vegetation interception should be able to capture seasonal dynamic of plant physiological development.

DREAM describes the interception process as a simple bucket of limited capacity $w_{s c}$, representing the value of maximum interception storage $[\mathrm{mm}]$ under the assumption that each leaf or needle is covered with a 0.2 -mm-thick water film on one side (Dickinson, 1984). Therefore:

$w_{s c}=0.2 \mathrm{LAI}(\mathrm{mm})$

The canopy water content is governed by a balance equation:

$\frac{\Delta w_{c}}{\Delta t}=p_{v}-e_{w c}$,

where $p_{v}$ is the interception rate and $e_{w c}$ is the direct evaporation rate.

According to Famiglietti and Wood (1994) direct evaporation of water from the canopy is assumed proportional to the wet canopy ratio $w_{w c}$ :

$e_{w c}=w_{w c} e_{\mathrm{wct}}$ if $w_{c}>0$

where: $w_{w c}=\left(w_{c} / w_{s c}\right)^{(2 / 3)}$ is the ratio of wet canopy (Deardorff, 1978) and $e_{\mathrm{wct}}$ is the potential evaporation rate from the entire canopy.

Total evapotranspiration $\left(E_{\mathrm{tot}}\right)$, is evaluated as the sum of evaporation from bare soil $e_{0}$ (due to water stored in surface depressions), and canopy evapotranspiration $\mathrm{ET}_{\mathrm{veg}}$. The distinction between vegetation cover and bare soil is based on the equation proposed by Eagleson (1982):

$M=1-e^{-\mu \mathrm{LAI}}$,

where $M$ represents the fraction of soil covered by vegetation, $\mu$ is an extinction coefficient which indicates the degree of decrease of light due to adsorption and scatter within a canopy. Equation (4) is one of the outcomes of the gapfraction theory by Larcher (1975). This theory states that, for whole canopies, the decrease in light intensity (light attenuation) with increasing depth of the canopy is described as an 
exponential decay with a coefficient representing a stand- or species-specific constant. Different types of vegetation have therefore different decay coefficient values, causing different rates of light attenuation for the same amount of leaf area. In this study, the values of $\mu$ were related to the land use, and the following values suggested by Larcher (1975) were used: 0.35 for grass, 0.45 for crops, 0.65 for trees.

The actual evapotranspiration from the canopy fraction $M$ of each basin cell is evaluated as:

$\mathrm{ET}_{\mathrm{veg}}=M \min \left(1, \frac{4}{3} \frac{S_{t}}{S_{\max }}\right) \mathrm{EP}^{\prime}$,

where $S_{\max }=\theta_{s} D$ is the soil water content at saturation $\left(\theta_{s}\right.$ is the volumetric soil moisture content at saturation, $D$ is the soil depth), $S_{t}$ is the soil water content at time $t$ and EP' is given by the potential evapotranspiration (EP) minus direct evaporation $\left(e_{w c}\right)$.

The actual evaporation from bare soil is evaluated by assuming that all the available water in depression storage evaporates until the potential rate is reached:

$e_{0}=(1-M) \min \left(\mathrm{EP}, w_{\mathrm{dep}}\right)$,

where $w_{\text {dep }}$ is the water storage of surface depressions. After canopy interception and surface depression storage are deducted, with regard to the hydrological processes that trigger runoff production, net precipitation infiltrates until the saturation capacity $S_{\max }$ of the soil is reached. As a consequence, surface runoff $R_{t}$ and infiltration $I_{t}$ are found as:

$R_{t}=P_{\text {net, } \mathrm{t}}-\left(S_{\max }-S_{t-1}\right)$ if $P_{\text {net, } \mathrm{t}} \geq\left(S_{\max }-S_{t-1}\right)$

$I_{t}=P_{\text {net, } \mathrm{t}}-R_{t}$ if $P_{\text {net, } \mathrm{t}}>0$,

where: $P_{\text {net } \mathrm{t}}=P_{t}-p_{v}-p_{\text {dep }}$ is the net precipitation in the time step $\Delta t$ (rainfall minus interception and surface storage).

\subsection{LAI-NDVI relationship}

The Leaf Area Index (LAI) is broadly defined as the projected leaf area per unit of ground area (Ross, 1981). LAI assumes different values according to belonging species and for the same species it varies with the stage of development and the crop technique.

Like net primary productivity (NPP), LAI is a key structural characteristic of vegetation and land cover because of the role of green leaves in a wide range of biological and physical processes. Data on estimates of LAI worldwide are needed by the scientific community investigating global scale fluxes and energy balance of the land surface. In fact, LAI provides an indicator of vegetation growth cycle and, as such, of the plant activity in terms of water transpiration. LAI can be derived from satellite data (e.g. NOAA-AVHRR) using multi-temporal NDVI images (e.g. McMichael, 2004).

In order to derive LAI from NDVI, the vegetation heterogeneity of Mediterranean regions, including soil disturbances (having a large influence on the spectral signatures), has to be considered. Thus the relationship between LAI and NDVI is not unambiguous and multiple values of NDVI may correspond to a single value of LAI. Moreover, the NDVI is closely related to the vegetation canopy LAI only if the plant cover is uniform, otherwise the effect of the undergrowth layer must be considered.

In erlier applications of DREAM the following linear equation suggested by Caraux-Garson et al. (1998) was used:

$\mathrm{LAI}=-0.39+6 \mathrm{NDVI}$.

Nevertheless, several authors (e.g. Asrar et al., 1984; Sellers, 1985; Fassnacht et al., 1997) report that the relationship between NDVI and LAI generally has a linear form only for LAI between zero and three because of the saturation effect on the greenness index with the increase of vegetation leaf area. In order to get a better description of the LAI distribution, a non-linear relationship such as the Beer's law (already applied by Lacaze et al. (1996) in a Mediterranean shrubland) can be used:

$\mathrm{LAI}=-\frac{1}{k} \ln \frac{\mathrm{NDVI}_{\mathrm{can}}-\mathrm{NDVI}}{\mathrm{NDVI}_{\mathrm{can}}-\mathrm{NDVI}_{\mathrm{back}}}$,

where $\mathrm{NDVI}_{\text {can }}$ (canopy) is the asymptotic value of NDVI for higher LAI values, NDVI $_{\text {back }}$ (background) is the NDVI value corresponding to bare soil (Baret and Guyot, 1991) and $k$ is the extinction coefficient. These parameters may depend on vegetation, soil and sensor types used for NDVI estimates. Several reference values are available in literature (see Brivio et al., 2006) for parameters depending on the peculiarity of the analyzed vegetation covers (Table 1). In particular, $k$ is the absorption-scattering coefficient that determines the sensitivity of the vegetation index to a unit increase of LAI. The extinction coefficient depends both on the sensor type and the canopy/vegetation characteristics as density, leaf angle distributions, soil optical properties and leaf physiological properties (Campbell, 1986; Maselli et al., 2004; Nouvellon et al., 2000; Wu et al., 2007). In other words, $k$ may have a very large range of variability even for a given vegetation type being this last also influenced by the foliage properties. In this paper, we analyze the influence of the extinction coefficient on the water balance, using first the value of $k$ suggested by literature for a Mediterranean environment (Hoff et al. 1995) and then proposing a calibration procedure for the investigated study area.

Figure 1 represents different LAI-NDVI relationships obtained using Eqs. (9) and (10), where NDVI can $_{\text {and }}$ NDVI $I_{\text {back }}$ are assumed as in Table 1, while the extinction coefficient ranges from 0.1 to 0.3 . This graph clearly shows the errors associated to a linear approximation for the LAI-NDVI relationship especially for smaller $k$ values (e.g., $k=0.1$ ). 
Table 1. Parameters of Beer's law: literature values referring to different vegetation and sensor types (Brivio et al., 2006).

\begin{tabular}{llllll}
\hline $\begin{array}{l}\text { Vegetation } \\
\text { type }\end{array}$ & NDVI $_{\text {back }}$ & NDVI $_{\text {can }}$ & $k$ & Sensor & Reference \\
\hline $\begin{array}{l}\text { Conifer } \\
\text { forest }\end{array}$ & 0.100 & 0.868 & 0.363 & $\begin{array}{l}\text { Landsat- } \\
\text { Tm }\end{array}$ & $\begin{array}{l}\text { Leblon et al. } \\
(1993)\end{array}$ \\
$\begin{array}{l}\text { Mediterra- } \\
\text { nean area }\end{array}$ & 0.224 & 0.859 & 0.213 & $\begin{array}{l}\text { Landsat- } \\
\text { Tm }\end{array}$ & $\begin{array}{l}\text { De Jong } \\
(1994)\end{array}$ \\
$\begin{array}{l}\text { Mediterra- } \\
\text { nean area }\end{array}$ & 0.225 & 0.862 & 0.212 & $\begin{array}{l}\text { NOAA- } \\
\text { AVHRR }\end{array}$ & $\begin{array}{l}\text { Hoff et al. } \\
(1995)\end{array}$ \\
\hline
\end{tabular}

\section{Study area and geographical database}

The Candelaro river basin, with area of $1980 \mathrm{~km}^{2}$ and mean elevation of $300 \mathrm{~m}$ is located in a temperate Mediterranean region (Puglia, Southern Italy, Fig. 2). The main river reach has its origins at the bottom of the Gargano headland, at $145 \mathrm{~m}$ a.s.l., and outlets after $67 \mathrm{~km}$ in the Adriatic Sea. The hydrologic regime is characterized by Mediterranean semiarid features like strong seasonality, intermittency and periodic occurrence of droughts and sudden floods.

A distinctive feature of the area is the intensive agricultural activity with a high percentage of soil destined to wheat, as such being cause of frequent water shortage conditions and massive groundwater exploitation. The watershed is characterized by substantial heterogeneity in morphology, geology and hydrology. The disomogeneity of Candelaro, which includes Appennine mountains, Capitanata plain and part of the Gargano headland, influences surface and underground discharge.

On the left of the main river reach the basin contributing area is rather small compared to the right one which is wide and ploughed by a large number of tributaries, mostly with intermittent regime. The main tributary, Celone $(62 \mathrm{~km})$, drains a sub-catchment of about $100 \mathrm{~km}^{2}$, it has an intermittent streamflow regime, with a dry period with negligible or null runoff lasting for more than three months on the average hydrologic year. The inter-annual variability of precipitation strongly affects the streamflow regime. The peculiarity of this sub-basin of Candelaro is the marked predominance of wheat cropped areas $(68 \%)$, followed by wooded surfaces $(24 \%)$ and olive groves (8\%).

The hydrological simulation was performed using daily series of rainfall and discharge recorded during the period 1976-1996. The spatial distribution of rainfall was accounted for by applying the Thiessen polygon method to five existing rainfall gauges (Faeto, Biccari, Orsara di Puglia, Orto di Zolfo, Troia). Other parameters regarding the basin morphology were obtained by the $90 \mathrm{~m}$ resolution DEM produced by the Shuttle Radar Topography Mission (SRTM) (Farr and Kobrick, 2000). Corine Land Cover 2000 was adopted to describe land use and vegetation coverage while

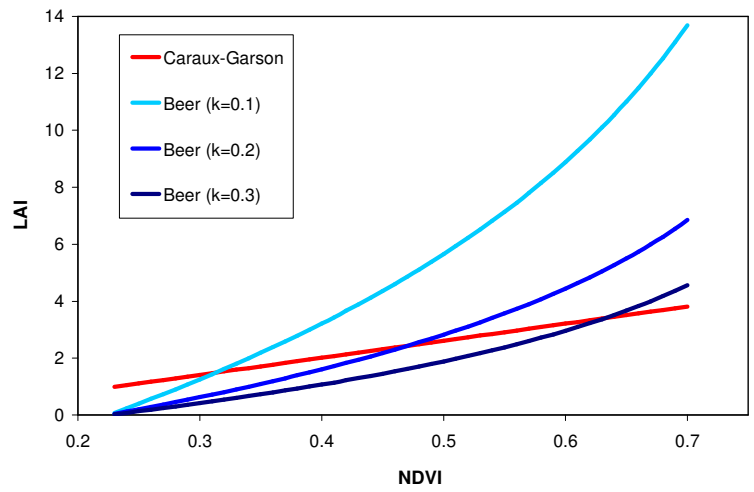

Fig. 1. LAI-NDVI relationship according to Caraux-Garson and Beer's law $\left(\mathrm{NDVI}_{\mathrm{back}}=0.225 ; \mathrm{NDVI}_{\mathrm{can}}=0.862\right)$.

the ACLA2 dataset (Caliandro et al., 2005) was exploited for the pedological characterization.

Monthly NDVImaps derived by $1 \times 1 \mathrm{~km}$ NOAA-AVHRR (Advanced Very High Resolution Radiometer, onboard National Oceanic and Atmospheric Administration satellites) data recorded in 1998 and calibrated using NOAA-NESDIS coefficients (Rao and Chen, 1999) were used for the description of vegetation cycle. The final NDVI product were obtained in form of monthly Maximum Value Composite (MVC) images mapped in a geographical reference system with a $1 \times 1 \mathrm{~km}$ pixel size. Thus, for the year 1998 , twelve 30-day MVC images were available (Fig. 2). The MVC technique retains the highest NDVI value for each pixel during a 30-day period producing images that are spatially continuous and relatively cloud-free, with temporal resolution sufficient for evaluating vegetation dynamics (Eidenshink, 1992; Holben, 1986; Simoniello et al., 2008).

LAI maps were derived using the different regression models above presented in Eqs. (9) and (10) and were used for model simulations. Unfortunately not any discharge record was available in 1998 and the 1976-1996 discharge time series was used for model verification. Therefore, vegetation status was treated as an invariant feature in the model development repeating its seasonal dynamic from one year to the other. The assumption of invariant land cover between 1998 (NDVI dataset), 2000 (Corine dataset) and the hydrologic record (1976-1996) is quite consistent for wheat coverage which is the traditional crop in those areas where no irrigation supply is available as occurs in most parts of the study catchment.

\section{Parameter estimation of the LAI-NDVI relationship}

As first working hypothesis, we have used the relationship proposed by Caraux-Garson (Eq. 9) and the Beer's law (Eq. 10) with parameters taken from the literature. In particular, the Beer's law was applied using the parameters of Table 1 suggested for Mediterranean area (Hoff et al., 

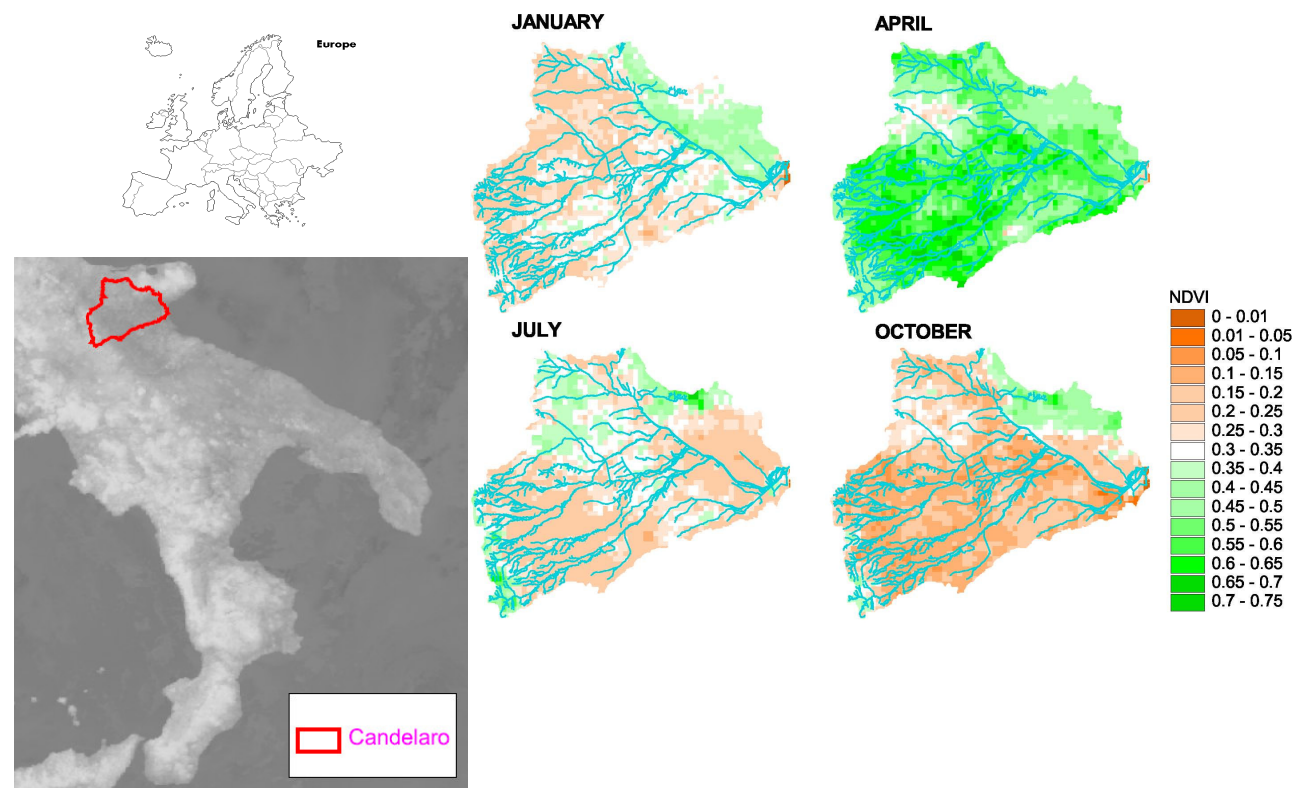

Fig. 2. NDVI maps of four months measured in 1998 over the Candelaro basin, Southern Italy.

$1995)$ using the AVHRR sensor $\left(k=0.212 ; \mathrm{NDVI}_{\mathrm{back}}=0.225\right.$; $\mathrm{NDVI}_{\mathrm{can}}=0.862$ ). We obtained significant differences in the empirical cumulative frequency distribution of LAI for April and December that are reported in Fig. 3a and c, being these months with the highest and the lowest values of NDVI, respectively. Such distributions include LAI values, within the Candelaro basin, covered by either cropland (63.6\% of the basin area), or shrubland (3.1\%), or deciduous vegetation (broadleaf and conifer for $0.2 \%$ ). In the same figures, we report as vertical lines some reference values (minimum and maximum) reported by literature (see Scurlock et al., 2001; Hagemann, 2002; LDAS, 2007 ${ }^{1}$ ) for the mentioned vegetation covers. The comparison in Fig. 3a shows that the function of Caraux-Garson provides values of LAI much smaller than those given by the literature in a period when vegetation has the most significant activity. On the other hand, the Beer law yields, especially in December, many negative LAI values which are physically inconsistent and have been replaced with zeros (see Fig. 3c). Such preliminary investigation indicates that, according to the available NDVI dataset, the $\mathrm{NDVI}_{\text {back }}$ parameter needs to be assumed equal to the minimum NDVI value observed in the dataset $\left(\mathrm{NDVI}_{\mathrm{back}}=0.0039\right)$, as suggested by Lacaze et al. (1996). On the other hand, the NDVI can $_{\text {suggested by }}$ Hoff et al. (1995) looks consistent with our dataset because not any exceedance of such asymptotic value was observed in the maximum values observed.

Particular attention is required also for the estimation of the extinction coefficient $k$. In principle, the extinction coefficient $k$ depends on vegetation density, then it could be

\footnotetext{
${ }^{1}$ Land Data Assimilation System, http://ldas.gsfc.nasa.gov.
}

considered as a distributed parameter assuming different values in any grid-cell. On the other hand its variability may be significantly due to the observed sample variability of the minimum NDVI values in space. We exploited decadal values of LAI provided for wheat crops, in our study area, by the MARS Crop Yield Forecasting System (CGMS software MARS-JRC-EC) developed at the JRC (Hooijer, 1993). In particular this provides a reliable estimation of yearly LAI profile and a reference value for the maximum $\mathrm{LAI}=6.17$ for wheat crop. Thus, for the estimation of $k$, we only focused on areas covered by wheat being, also, this crop the dominant cover of the examined database and we gave strong consideration to the local variability range of the NDVI values observed in each cell of the considered area (Fig. 4a and b). We derived the cell-dependent $k$ values rewriting Eq. (10) as:

$k=-\frac{1}{\mathrm{LAI}_{\max }} \ln \frac{\mathrm{NDVI}_{\mathrm{can}}-\mathrm{NDVI}_{\mathrm{max}}}{\mathrm{NDVI}_{\mathrm{can}}-\mathrm{NDVI}_{\mathrm{back}}}$

and fixing the maximum LAI ( $\mathrm{LAI}_{\max }$ ) equal to 6.17 (Hooijer, 1993), NDVI can $_{\text {en }}$ equal to 0.862 (Hoff et al., 1995), $\mathrm{NDVI}_{\max }$ and NDVI $\mathrm{I}_{\text {back }}$ equal to, respectively, the local maximum and minimum NDVI values observed in each cell. Figure $4 \mathrm{a}$ and $\mathrm{b}$ shows the absolute frequency of, respectively, the minimum and maximum NDVI values observed in each pixel of the map. These values were used in Eq. (11) in order to obtain the $k$ values whose distribution is displayed in Fig. 4c. Finally we assumed $k$ equal to the mode value 0.17 , as representative of the wheat crops in the study area.

In order to evaluate the reliability of the proposed estimation procedure of $k$ we selected 5 homogeneous samples areas of wheat crop in the basin (Fig. 6). They were found by comparative examination of Corine land cover maps with 
(a) April

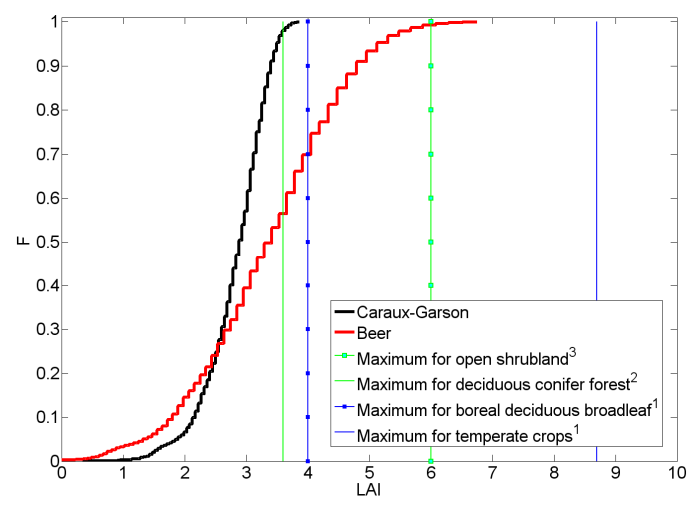

(c) December

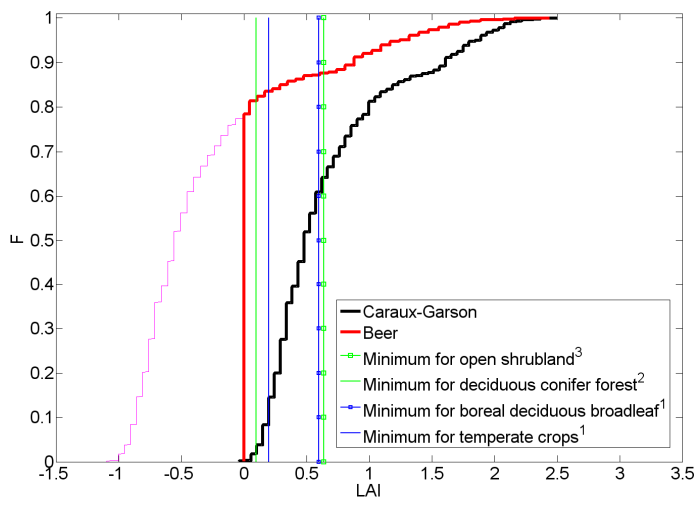

(b) April

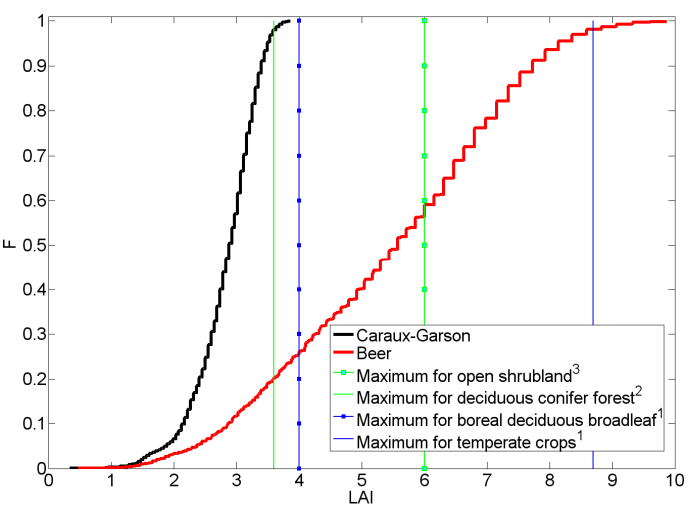

(d) December

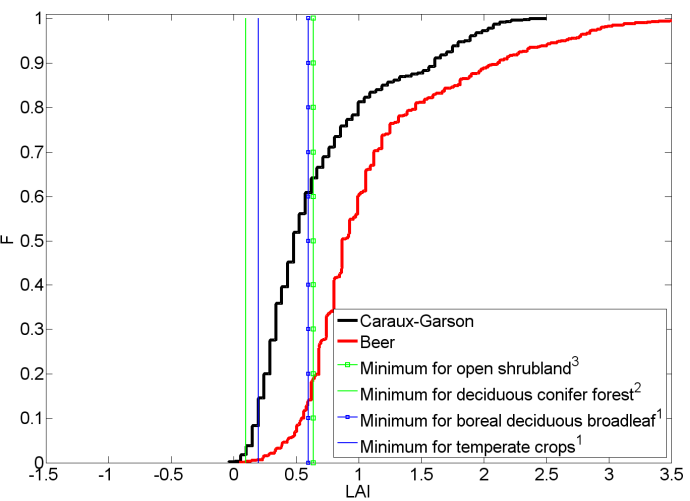

Fig. 3. Empirical cumulative distribution functions of LAI referring to all vegetation types covering the Candelaro basin obtained with different LAI-NDVI relationships. In (a) April and (c) December, $\mathrm{NDVI}_{\mathrm{back}}=0.225, \mathrm{NDVI}_{\mathrm{can}}=0.862, k=0.212$. In (b) April and (d) December, $\mathrm{NDVI}_{\mathrm{back}}=0.0039, \mathrm{NDVI}_{\mathrm{can}}=0.862, k=0.17$.

${ }^{1}$ Scurlock et al. (2001). ${ }^{2}$ Hagemann (2002). ${ }^{3}$ Value available on http://ldas.gsfc.nasa.gov.

aerial photos of 2000 and 2006 provided by the Italian Environment Ministry $(2007)^{2}$. Each sample area, of size $4 \mathrm{~km} \times 4 \mathrm{~km}$, includes 16 cells of the NDVI maps. In Fig. 5 the estimated monthly LAI profiles of the 5 homogeneous samples and a curve representing the mean of all wheat cells within the investigated area are compared with the expected monthly LAI profile (as derived from CGMS software MARS-JRC-EC, Hooijer, 1993). In the graphs, four different parameter sets are used (see Table 2). In particular, Fig. 5a is obtained assuming the literature value of $k=0.212$ while Fig. $5 \mathrm{~b}, \mathrm{c}$ and $\mathrm{d}$ uses the estimated value $k=0.17$. Moreover, in Fig. 5a and b, the NDVI back is assumed equal to the minimum NDVI observed in the whole wheat area. Figure $5 \mathrm{c}$ is obtained by assuming $\mathrm{NDVI}_{\text {back }}$ equal to the average minimum NDVI estimated from the distribution shown in Fig. 4a. Figure $5 \mathrm{~d}$ has a different $\mathrm{NDVI}_{\text {back }}$ for any curve which is the minimum NDVI value in the sample area. In all graphs, the

\footnotetext{
${ }^{2}$ Ministero dell'Ambiente e della Tutela del Territorio e del Mare, http://www.pcn.minambiente.it.
}

$\mathrm{NDVI}_{\text {can }}$ is always equal to the literature value 0.862 . All figures highlight the strong LAI variability observed between different sample sites of the same land-cover in both peak and peak time.

In particular, the time profile of the LAI referred to "Site 4" is always quite higher than others and it has always the maxima simulated values in April. Differences between the local vegetation patches and the expected LAI profiles can be related to the co-existence of different seasonal species with slightly shifted phenological cycles (cultivars) in the same geographical area. Also, one should consider that these analyses were performed using only one year of observations (1998). The use of the estimated $k$ value (Fig. 5b), instead of the literature one (Fig. 5a) suggested by Hoff et al. (1995), causes, in all sample sites and for all months, a light overestimation of LAI. For what concerns the $\mathrm{NDVI}_{\text {back }}$, we can notice that, though the NDVI $\mathrm{Iack}_{\text {bal }}$ equal to 0.1123 is statistically consistent (Fig. $5 \mathrm{c}$ ), the best fitting is given for sample sites by an NDVI back equal to the sample minimum value (Fig. 5d), and for the whole basin average 
(a)

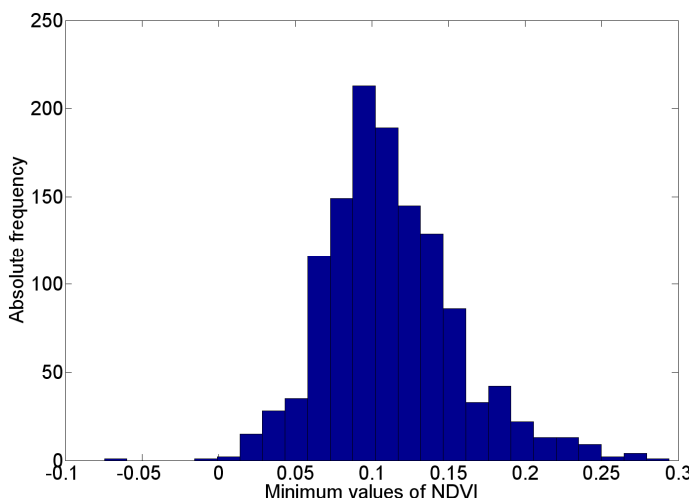

(b)
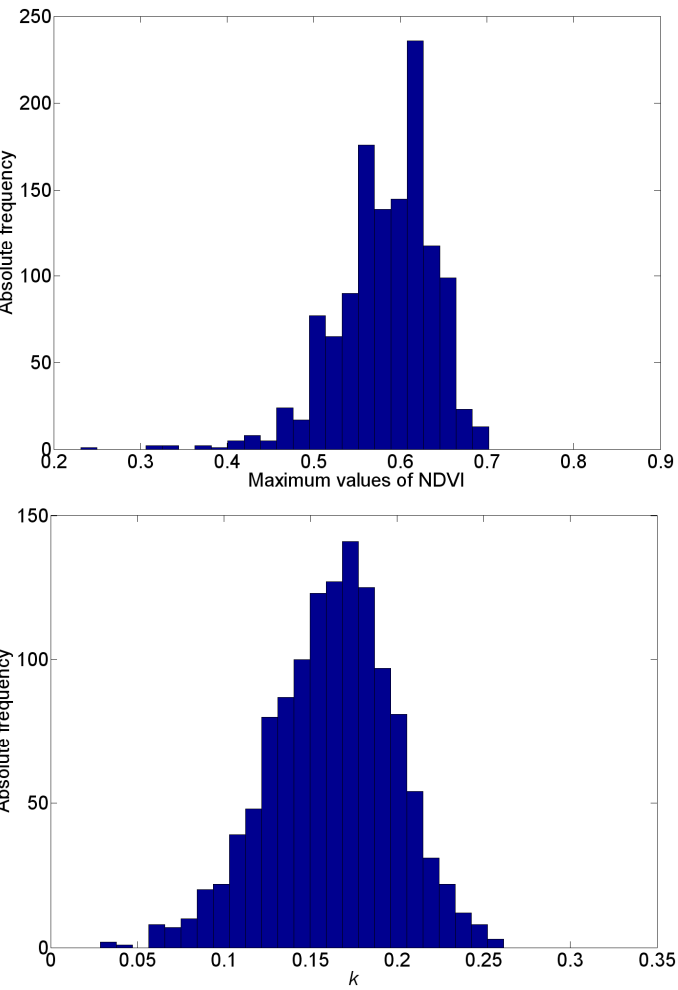

(c)

Fig. 4. Absolute frequency distribution of the minimum (a) and maximum (b) recorded values of NDVI for the multi-temporal maps of the study area; and the corresponding extinction coefficients $k$ calculated from Eq. (10) (c). Shown distributions regard wheat crops in the entire Candelaro basin and refer to year 1998.

by $\mathrm{NDVI}_{\text {back }}$ equal to the minimum value in map (0.0039, Fig. 5b). This particular value, also provides a slight overestimation of LAI values in months of very low vegetation cover where the LAI should be equal to zero. (July-January). This bias was expected because we assumed the NDVI $_{\text {back }}$ equal to the minimum value in map in order to avoid the presence of negative values of LAI which are physically inconsistent (Fig. 5c). Moreover, the overestimation of LAI values for the period July-January could be ascribed to the presence of weeds which are not accounted in LAI simulation. However, the effect of this bias, is less important with respect to the hydrological evaluation of water balance for two reasons:
Table 2. Parameters of Beer's law: results of calibration applied to wheat.

\begin{tabular}{|c|c|c|}
\hline $\begin{array}{l}\text { Beer's law } \\
\text { parameters }\end{array}$ & $\begin{array}{l}\text { Calibrated } \\
\text { value }\end{array}$ & $\begin{array}{l}\text { Method of } \\
\text { calibration }\end{array}$ \\
\hline$k$ & 0.17 & $\begin{array}{l}\text { Mode of } k \\
\text { frequency distribution }\end{array}$ \\
\hline $\mathrm{NDVI}_{\text {back }}$ & 0.0039 & $\begin{array}{l}\text { Minimum recorded } \\
\text { value of NDVI }\end{array}$ \\
\hline $\mathrm{NDVI}_{\text {back }}$ & 0.1123 & $\begin{array}{l}\text { Mean of frequency } \\
\text { distribution referred } \\
\text { to minimum recorded } \\
\text { NDVI values }\end{array}$ \\
\hline $\mathrm{NDVI}_{\text {back }}$ & $\begin{array}{l}0.0667(\text { Site } 1) \\
0.1373(\text { Site } 2) \\
0.0745(\text { Site } 3) \\
0.0510(\text { Site } 4) \\
0.0588(\text { Site } 5)\end{array}$ & $\begin{array}{l}\text { Minimum recorded } \\
\text { value of NDVI } \\
\text { referred to } \\
\text { sample sites }\end{array}$ \\
\hline
\end{tabular}

(1) the role of evapotranspiration is much more effective in months from March to June, when wheat reaches maximum productivity; (2) the slight overestimation of LAI in other months is practically at least partially compensated by the heterogeneity of soil coverage which is always present to a certain extent in large cells of $1 \mathrm{~km} \times 1 \mathrm{~km}$.

The final step in this rationale for the estimation of the parameters of the Beer's law consists of an analysis of consistency of the obtained LAI maps. To describe the spatial variability of the vegetation cover we represent the cumulative frequency distribution of the LAI referred to the vegetation types of the area. In detail for the Beer's law, we adopt the calibrated parameters found in the previous paragraph for wheat crops $\left(\mathrm{NDVI}_{\text {back }}=0.0039, k=0.17 ; \mathrm{NDVI}_{\mathrm{can}}=0.862\right)$, while for the other vegetation types we have considered the literature values (Hoff et al., 1995) for $k$ and NDVI $_{\text {can }}$ and the specific minimum recorded value of NDVI as NDVI $\mathrm{N}_{\text {back }}$. The results are shown in Fig. $3 b$ and d. Comparing Fig. 3a and $\mathrm{c}$ to, respectively, Fig. $3 \mathrm{~b}$ and $\mathrm{d}$, we can conclude that, in general, the calibrated Beer law provide "better" results referring to both no-calibrated Beer's and Caraux-Garson's law. In particular:

- in April the calibrated Beer's and the Caraux-Garson's law provides very different outputs, with distributions different for shape and position;

- in April only the calibrated Beer's law provides a LAI distribution which satisfactory relates to the reference vertical lines for different vegetation covers (Scurlock et al., 2001; Hagemann, 2002; LDAS, 2007 ${ }^{1}$ );

- In December not any negative value is provided by the calibrated Beer's law. 
(a) $k=0.212 ; \mathrm{NDVI}_{\mathrm{back}}=0.0039 ; \mathrm{NDVI}_{\mathrm{can}}=0.862$

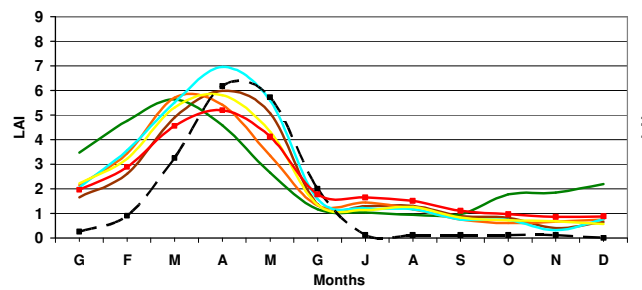

(c) $k=0.17 ; \mathrm{NDVI}_{\mathrm{back}}=0.1123 ; \mathrm{NDVI}_{\mathrm{can}}=0.862$

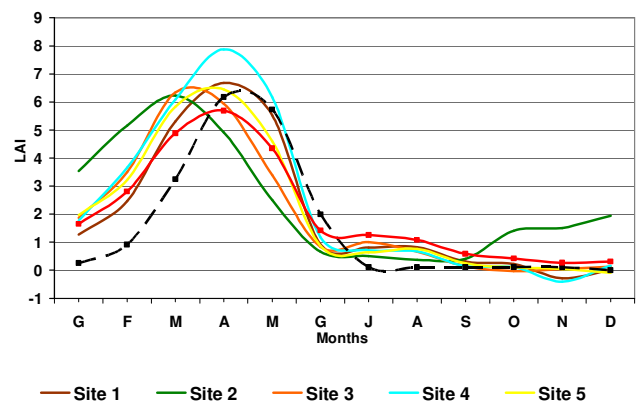

(b) $k=0.17 ; \mathrm{NDVI}_{\text {back }}=0.0039 ; \mathrm{NDVI}_{\text {can }}=0.862$

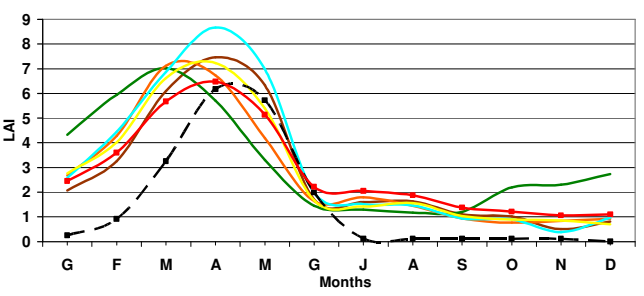

(d) $k=0.17 ; \mathrm{NDVI}_{\text {back }}$ equal to sample minimum value; $\mathrm{NDVI}_{\text {can }}=\mathbf{0 . 8 6 2}$

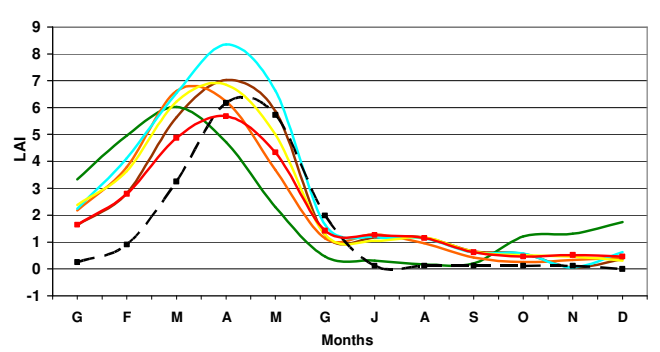

$\rightarrow-$ Literature values $\quad \rightarrow$ Mean sim. values (whole basin)

Fig. 5. Time profiles of LAI for wheat (sample sites and whole basin). Expected values and estimates obtained with the Beer's law, for different sets of $k(\mathbf{a}, \mathbf{b})$ and $\mathrm{NDVI}_{\text {back }}(\mathbf{b}, \mathbf{c}, \mathbf{d})$. Expected values from CGMS software MARS - JRC - EC (Hooijer et al., 1993).

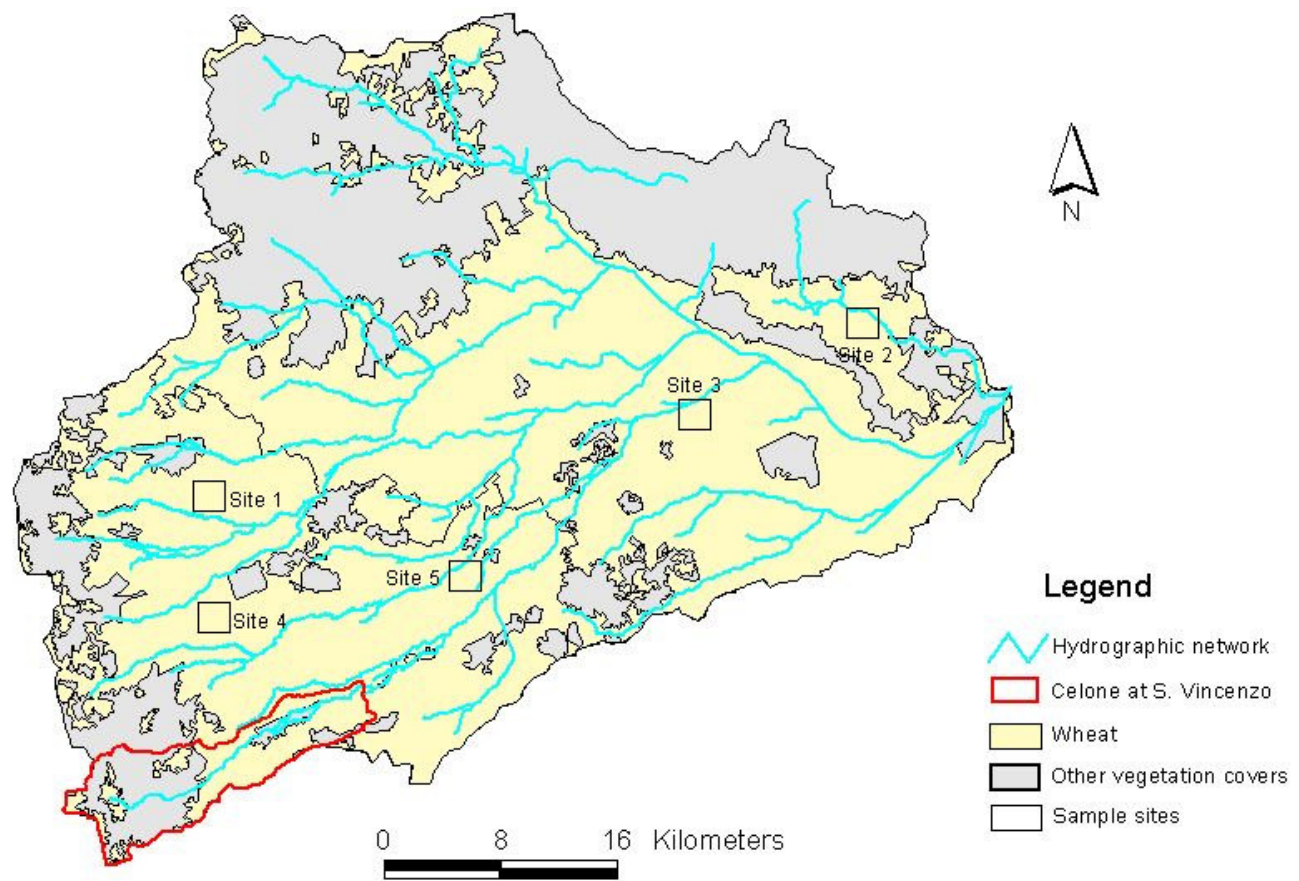

Fig. 6. Wheat sample sites in Candelaro basin and Celone sub-basin.

- in December the calibrated Beer's law and the one of Caraux-Garson provide similar distributions in shape. Only an average 0.5 horizontal shift separates the two distributions with a probable slight overestimation provided by the Beer's law, as already mentioned for Fig. 5 .
In order to evaluate the effective impact of such different LAI distributions on water balance, in the next section both the calibrated Beer's and the Caraux-Garson's law will be considered again. 
(a) Caraux-Garson

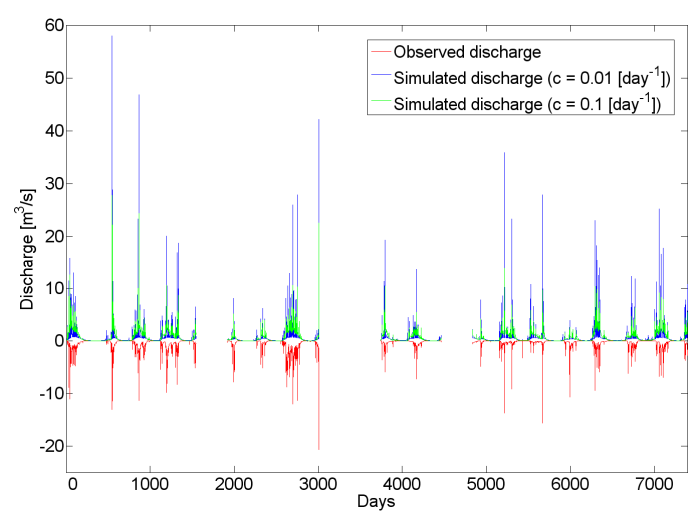

(c) Caraux-Garson

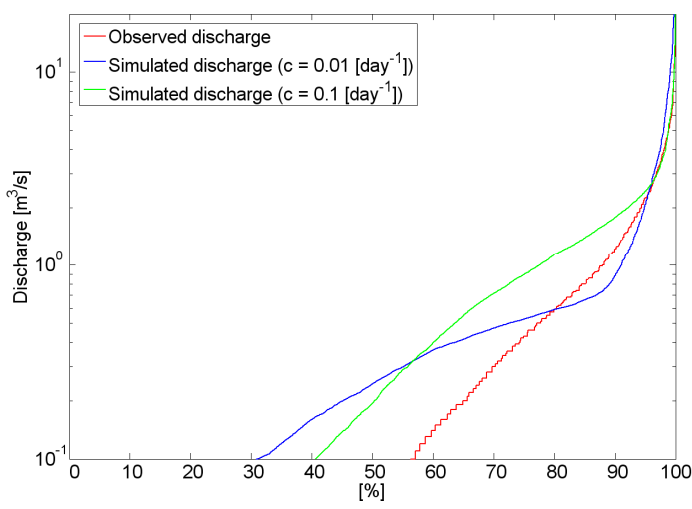

(b) Beer

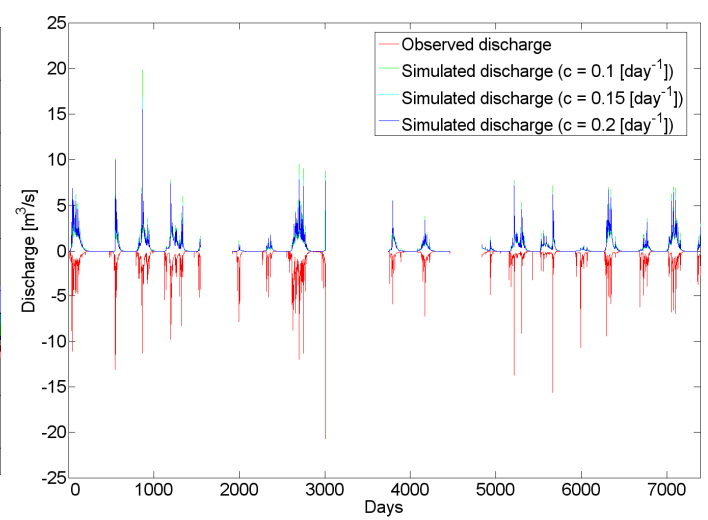

(d) Beer

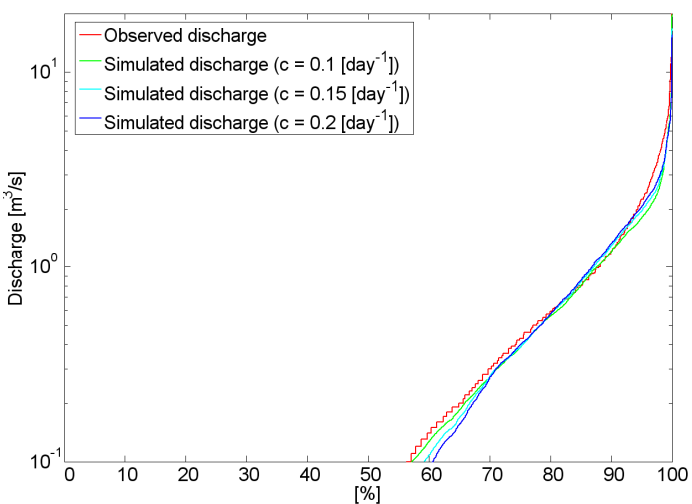

Fig. 7. Simulated vs. recorded stream flows time series $(\mathbf{a}, \mathbf{b})$ and flow duration curves $(\mathbf{c}, \mathbf{d})$ using different LAI-NDVI regressions.

\section{DREAM model application}

In this section, we investigated how improvements of vegetation dynamics evaluations impact on water balance predictions. To this end, the DREAM was applied to the Celone sub-basin of Candelaro, where the anthropogenic disturbances to the hydrological regime is negligible (i.e. limited groundwater exploitation and hydraulic works). The time delay of the groundwater component contributing to the streamflow hydrograph, (being the response of the groundwater storage interpreted as linear reservoir) was set equal to 14 days according to the observed baseflow recession constants.

DREAM was applied to Celone considering both cases: (1) LAI evaluated according to Caraux-Garson law; (2) LAI evaluated with calibrated Beer's law $\left(\mathrm{NDVI}_{\text {back }}=0.0039\right.$, $k=0.17 ; \mathrm{NDVI}_{\mathrm{can}}=0.862$ ).

Results are shown in form of stream flow time series and flow duration curves (FDC) relative to the period 1976-1996 (Fig. 7). The interruptions in the stream flow time series (observed in the years 1981, 1985, 1986, 1989) are due to the absence of recorded data. In the application of Caraux-Garson, negative values of LAI were set equal to zero.
The DREAM simulations refer to different values of the "subsurface flow coefficient" $c$, parameter of calibration of the hydrological model at the daily time scale. This parameter, which is a function of lateral hydraulic conductivity, is assumed as a basin constant and was calibrated considering a simulation efficiency measure related to the reliable prediction of water balance components. The value of $c$ which provided the minimum Root Mean Square Error (RMSE) was chosen (Table 3) as the best fit for the model calibration. Due to the particular intermittent regime of Celone, only streamflow observation greater than $0.1 \mathrm{~m}^{3} / \mathrm{s}$ were used for the evaluation of the RMSE. Lower discharge values (greater than $0.01 \mathrm{~m}^{3} / \mathrm{s}$ ) are also present in the data, nevertheless we did not considered them because they are affected by the unreliability of the available rating curves for small water depths.

Results reported in Fig. 7, suggest that LAI maps obtained by the Caraux-Garson's law, produce a dramatic underestimation of evapotranspiration which is strongly reflected by the flow duration curves in Fig. 7c. We only report DREAM simulations obtained for $c=0.1$ and $c=0.01$. The first value $(0.1)$ provides a consistent overestimation of the low flows for a wide range of durations (up to 90\%). Different values of $c$ do not provide better results, in fact values 
Table 3. Simulation efficiency in terms of root mean square error (RMSE) used for calibration of the subsurface flow coefficient $c$, for different LAI-NDVI relationships.

\begin{tabular}{llllll}
\hline & \multicolumn{2}{c}{ Caraux-Garson } & \multicolumn{3}{c}{ Beer } \\
\hline$c$ day $\left.^{-1}\right]$ & 0.01 & 0.10 & 0.10 & 0.15 & 0.20 \\
RMSE $\left[\mathrm{m}^{3} / \mathrm{s}\right]$ & 2.36 & 1.21 & 1.17 & 1.16 & 1.17 \\
\hline
\end{tabular}

greater than 0.1 produce still an overestimation of the baseflow, while values of $c$ lower than 0.1 produce an increase in the surface runoff changing the shape of the FDC.

Better results are obtained using the LAI maps estimated by the Beer's law. Figure $7 \mathrm{~b}$ and d shows the results of the best fitting calibration procedure based on the minimization of the RMSE. Interestingly we found $c=0.15$ as the best fitting value, slightly lower than 0.25 wich was used in previous DREAM applications to other Mediterranean basins (e.g. Manfreda et al., 2005). Such a difference is probably due to the different climatic signature (semi-arid climate) which characterizes the Candelaro basin. Also a scale effects in the process of redistribution may affect the value of $c$ because the grid cell size adopted $(90 \mathrm{~m})$ in the present work is smaller than the one of previous applications $(240 \mathrm{~m})$. The visual comparison of flow duration curves (simulated vs. observed) provides satisfactory results. The model descriptive capacity with reference to low flows is excellent as well as the reproduction of intermittency characterized by quasi-zero flows for a duration between $55 \%$ and $60 \%$.

The analysis of Fig. 7c and d highlighted a modest sensitivity to the parameter $c$ for the DREAM simulations. This result is physically consistent because this parameter controls the lateral redistribution of subsurface runoff flows that in the present basin plays a secondary role given the climatic conditions of the basin. Much larger impact is due to LAI values which controls basin evapotranspiration. In order to provide deeper insights into the role of LAI maps in water balance and by the light of previous results about the uncertainty of the LAI-NDVI relationships (e.g. Fig. 1), a sensitivity analysis of DREAM results was performed with respect to the extinction coefficient $k$ of the Beer's law.

\section{Sensitivity analysis of water balance components to $k$}

To understand how LAI estimations may influence the simulated water balance components, a sensitivity analysis was carried out changing the values of the extinction coefficient $k$ in the range $0.1-0.3$ only for wheat vegetated areas, while for the other vegetation types we kept $k=0.212$. This choice was motivated by the need to understand how the hydrologic losses such as evapotranspiration and streamflow are controlled by the density of vegetation cover in a region where

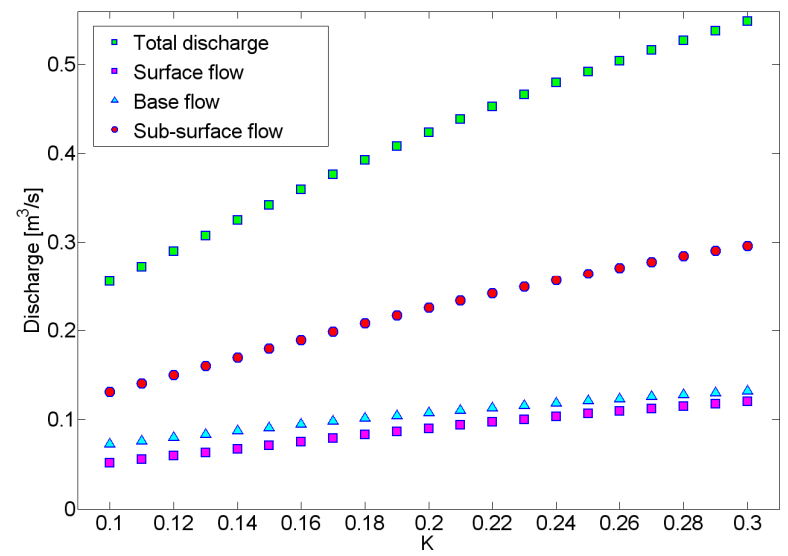

Fig. 8. Influence of the extinction coefficient $k$ on the hydrological components.

the parametric uncertainty due to spatial heterogeneity of measurements is mainly characterized by wheat crops that represent the most part of the basin area.

The influence of different values of $k$, that is introduced in the simulation model as an equivalent parameter of the observable spatial variability, was first considered on the mean component of the discharge hydrograph, namely, surface, sub-surface and base flow (Fig. 8). Not surprisingly increasing $k$ correspond to a linear reduction of the LAI in the Beer's law and therefore to more water available for surface runoff and groundwater recharge. Conversely, greater values of $k$ imply a reduction in the hydrologic losses due to vegetation and increase in bare soil evaporation (Fig. 9).

Looking more in details at the temporal variability of the three streamflow components, as shown in the flow duration curves in Fig. 10, the sensitivity of the dominant hydrological processes to the water losses due to vegetation can be clearly depicted. From such analysis, in fact, sub-surface flow and base-flow seem to be highly influenced by vegetation cover, while surface flow appears less impacted. This latter feature may originate from the generation process of surface runoff events that, at least in the hydrologic context of the study site, correspond to heavy rainfall conditions during which vegetation cover has limited influence.

The sensitivity analysis to the scaling factor $k$ was also addressed to the soil moisture and evapotranspiration response at the catchment scale. For three values of $k$ in the range specified above, the empirical frequency distributions of daily soil moisture (Fig. 11a) and total evapotranspiration (Fig. 11b) averaged over the catchment area were obtained from the entire simulated period. The frequency distributions show a significant dependence from the LAI parameter for both the two derived variable. In particular, the soil moisture distributions, having a bimodal shape for all the three $k$ values $(0.1 ; 0.2 ; 0.3)$ reflecting the seasonality of climate and vegetation dynamics, show an increased frequency of wetter conditions with increasing of $k$ values. 

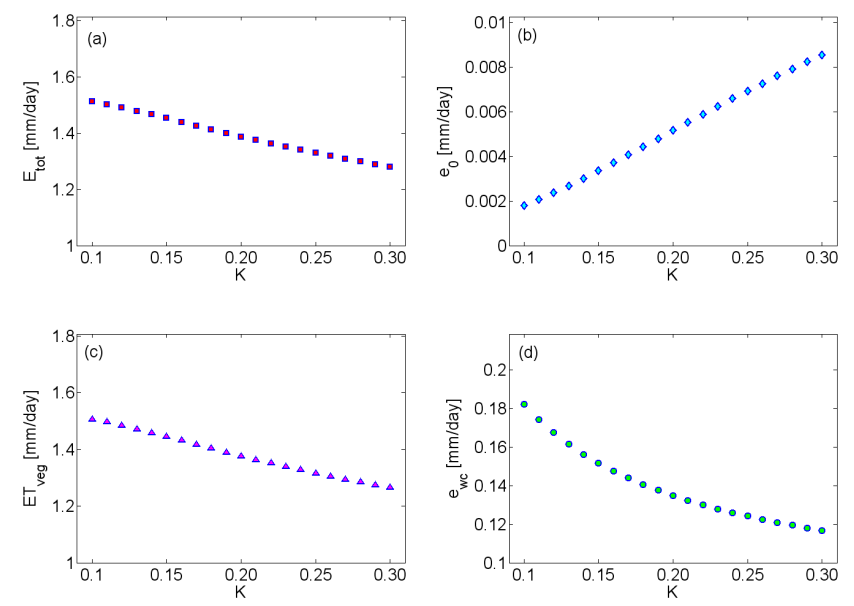

Fig. 9. Influence of the extinction coefficient $k$ on total evapotranspiration (a), evaporation from bare soil (b), evapotranspiration from canopy fraction (c) and direct evaporation from canopy (d).
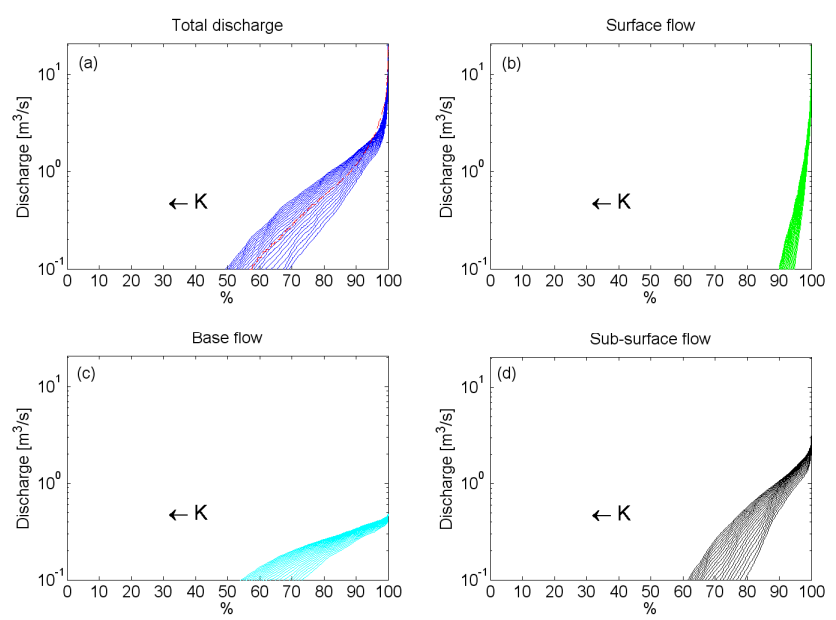

Fig. 10. Flow Duration curves referred to different hydrological components, obtained by varying the extinction coefficient in the range $0.1-0.3$. The red line in (a) represents the observed discharge.

Similarly, also the frequency distribution of the spatial average evapotranspiration has a bimodal shape in all of the three parameter values. In this case, the first frequency maximum corresponding to the minimum evapotranspiration values represent the period of lower LAI values (i.e. from summer until late autumn and early winter) while the second frequency maximum refers to the season of full development of the vegetation cover and is therefore conditioned by the maximum annual LAI that in turn is controlled by the value of $k$.
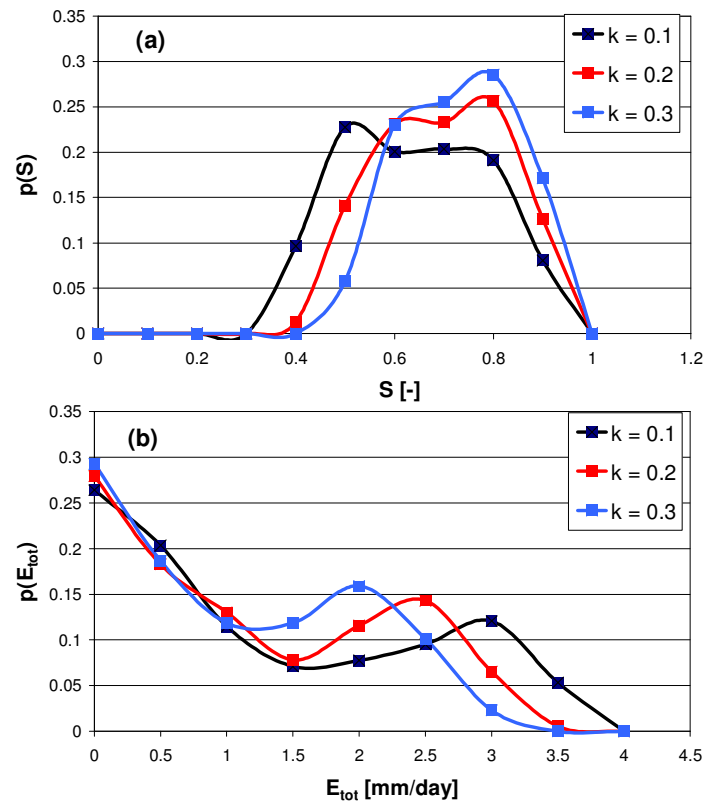

Fig. 11. Probability density functions of (a) relative saturation and (b) total evapotranspiration, for different $k$ values.

\section{Conclusions}

The fundamental role of vegetation dynamics on evapotranspiration, soil moisture and streamflow regimes was investigated in a typical Mediterranean catchment using the DREAM model in which the activity of vegetation coverage is described in terms of LAI. In this context, the application of a methodology for the evaluation of multi-temporal LAI maps though the combined use of NDVI images and literature LAI observations (related to the specific vegetation types found in the study area) was validated in terms of predictive performance of the adopted hydrologic model.

A comparison of two different regression models, CarauxGarson and Beer, to estimate the LAI from NDVI was performed. The application of the non-linear relationship (Beer's law) was demonstrated to be intrinsically better suited for environments characterized by low vegetation density and rapidly evolving cover types ranging from bare-soil conditions and high LAI values. Moreover, the other advantage is in the possibility to estimate the Beer's law coefficients from the available dataset obtaining more realistic LAI values for the vegetation covers of the study site.

Water balance simulation were performed as a validation of the adopted methodology and a way to investigate the influence vegetation activity on water balance component that may result from an erroneous estimation of the LAI maps. The reported results remark the key role of vegetation behavior in the dynamic evolution of soil water balance and therefore in determination of realistic patterns of soil moisture within catchment which also represent a prerequisite for 
the reliable reconstruction of flood processes. In the adopted framework, the realistic reconstruction of the dynamic evolution of vegetation cover at the catchment scale represented a way for the internal verification of the model components rather than a mere parameter estimation procedure.

Acknowledgements. The authors are grateful to the editor and two anonymous reviewers for their useful suggestions. This work was supported by MIUR (Italian Ministry of Instruction, University and Research) as PRIN CoFin2007 "Relations between hydrological processes, climate, and physical attributes of the landscape at the regional and basin scales".

Edited by: N. R. Dalezios

Reviewed by: two anonymous referees

\section{References}

Asrar, G., Fuchs, M., Kanemasu, E. T., and Hatfield, J. L.: Estimating absorbed photosynthetic radiation and leaf area index from spectral reflectance in wheat, Agron. J., 76, 300-306, 1984.

Baret, F. and Guyot, G.: Potential and limits of vegetation indeces for LAI and APAR assessment, Remote Sens. Environ., 35, 161173, 1991.

Beven, K. J. and Kirby, M. J.: A physically-based variable contributing area model of basin hydrology, Hydrological Sciences, Bulletin, 24, 43-69, 1979.

Brivio, P. A., Lechi, G., and Zilioli, E.: Principi e metodi di Telerilevamento, CittàStudi Edizioni, 2006 (in Italian).

Caliandro, A., Lamaddalena, N., Stelluti, M., and Steduto P.: ACLA 2 Project - Agro-Ecologic characterization of the Puglia region, CHIEAM IAM-B, 2005.

Campbell, G. S.: Extinction coefficients for radiation in plant canopies calculated using an ellipsoidal inclination angle distribution, Agr. Forest Meteorol., 36, 317-321, 1986.

Caraux-Garson, D., Lacaze, B., Scala, F., Hill, J., and Mehl, W.: Ten years of vegetation cover monitoring with LANDSAT-TM remote sensing, an operational approach of DeMon-2 in Languedoc, France, Symposium on operational remote sensing for sustainable development, Enschede, Nederlands, 1998.

Chang, M.: Forest and precipitation, Forest hydrology: an introduction to water and forest, Boca Raton, CRC Press, 2003.

Ciarapica, L. and Todini, E.: TOPKAPI: a model for the representation of the rainfall-runoff process at different scales, Hydrol. Process., 16, 207-229, 2002.

De Jong, S. M.: Derivation of vegetative variables from a Landsat TM image for modelling soil erosion, Earth Surf. Proc. Land., 19, 165-178, 1994.

Deardorff, J. W.: Efficient prediction of ground surface temperature and moisture, with inclusion of a layer of vegetation, J. Geophys. Res., 82, 1889-1903, 1978.

Dickinson, R. E.: Modelling evapotranspiration for three dimensional global climate models, in: Climate Processes and Climate Sensitivity, edited by: Hansen, E. and Tekahashi, T., AGU, Washington, DC, Geophys. Monogr. Ser., 29, 58-72, 1984.
Eagleson, P. S.: Ecological optimality in water limited natural soil vegetation system. I - Theory and Hypothesis, Water Resour. Res., 18(2), 325-340, 1982.

Eidenshink, J. C.: The 1990 conterminous U.S. AVHRR data set, Photogramm. Eng. Rem. S., 58, 809-813, 1992.

Famiglietti, J. S. and Wood, E. F.: Multi-Scale Modeling of Spatially-Variable Water and Energy Balance Processe, Water Resour. Res., 30, 3061-3078, 1994.

Farr, T. G. and Kobrick, M.: Shuttle Radar Topography Mission produces a wealth of data, Amer. Geophys. Union Eos, 81, 583585, 2000.

Fassnacht, K. S., Gower, S. T., MacKenzie, M. D., Nordheim, E. V., and Lillesand, T. M.: Estimating the leaf area index of north central Wisconsin forests using the Landsat Thematic Mapper, Remote Sens. Environ., 61, 229-245, 1997.

Federer, C. A.: Brook 90: a simulation model for evaporation, soil water, and streamflow, Version 3.1. Computer freeware and documentation, USDA Forest Service, Durham, NH 03824, 1995.

Fiorentino, M., Manfreda, S., and Iacobellis, V.: Peak Runoff Contributing Area as Hydrological Signature of the Probability Distribution of Floods, Adv. Water Resour., 30(10), 2123-2134, 2007.

Grayson, R. B., Blöschl, G., and Moore, I. D.: Distribute parameter hydrologic modelling using vector elevation data: THALES and TAPES-C, in: Computer models of watershed hydrology, edited by: Singh, V. P., Water Resources Publications, chapter 19, 1130 pp., 1995.

Gurtz, J., Baltensweiler, A., Lang, H., Menzel, L., and Schulla, J.: Auswirkungen von klimatischen Variationen auf Wasserhaushalt und Abfluss im Flussgebiet des Rheins, vdf, Hochschulverlag ETH Zurich, 1998.

Hagemann, S.: An improved land surface parameter dataset for global and regional climate models, Max Plank Institute for Meteorology, Hamburg, 2002.

Hoff, C., Bachelet, D., Rambal, S. Joffre, R., and Lacaze, B.: Simulating leaf area index of Mediterranean evergreen oak ecosystems: comparison with remotely sensed estimation, Proceedings of the International Colloquium Photosynthesis and Remote Sensing, Montpellier, France, 313-321, 28-30 August 1995.

Holben, B. N.: Characteristics of maximun-value composite images from temporal AVHRR data, Int. J. Remote Sens., 7, 1417-1434, 1986.

Hooijer, A. A., Bulens, J. D., and van Diepen, C. A.: SC technical document 14.1. CGMS version 1.1. System description. Technical document 14.2 CGMS version 1.1. User manual. Technical document 14.3. CGMS version 1.1. Program description. DLO Winand Staring Centre, Wageningen, The Netherlands and the Joint Research Centre, Ispra, Italy, 1993.

Hyndman, D. W., Kendall, A. D., and Welty, N. R. H.: Evaluating Temporal and Spatial Variations in Recharge and Streamflow Using the Integrated Landscape Hydrology Model (ILHM), AGU Monograph, Data Integration in Subsurface Hydrology, 2007.

Kennel, M.: Modellierung des Waasserhaushalts von Waldökosystemen, Forstliche Forschungsberichte, Faculty of Forestry, University of Munich, 1998.

Lacaze, B., Caselles, V., Coll, C., Hill, H., Hoff, C., de Jong, S., Mehl, W., Negendank, J. F., Riesebos, H., Rubio, E., Sommer, S., Teixeira Filho, J., and Valor, E.: DeMon, Integrated approaches to desertification mapping and monitoring in the Mediterranean 
basin. Final report of De-Mon I Project, Joint, Research Centre of European Commission, Ispra (VA), Italy, 1996.

Larcher, W.: Physiological Plant Ecology, Springer Verlag, New York, 1975.

Leblon, B., Granberg, H., Annseau, C., and Royer, A.: A semiempirical model to estimate the biomass production of forest canopies from spectral variables. Part 1: Relationships between spectral variables and light interception efficiency, Remote Sensing Reviews, 7, 109-125, 1993.

Manfreda, S., Fiorentino, M., and Iacobellis, V.: DREAM: a distributed model for runoff, evapotranspiration, and antecedent soil moisture simulation, Adv. Geosci., 2, 31-39, 2005, http://www.adv-geosci.net/2/31/2005/.

Maselli, F., Chiesi, M., and Bindi, M.: Multi-year simulation of Mediterranean forest transpiration by the integration of NOAAAVHRR and ancillary data, Int. J. Remote Sens., 25(19), 39293941, 2004.

McMichael, C. E.: Modeling the Effects of Fire on Streamflow in a Chaparral Watershed, Ph.D. thesis, University of California Santa Barbara, 2004.

Nouvellon, Y., Begue, A., Moran, M. S., Lo Seen, D., Rambal, S., Luquet, D., Chehbouni, G., and Inoue, Y.: PAR extinction in shortgrass ecosystems: effects of clumping, sky conditions and soil albedo, Agr. Forest Meteorol., 105, 21-41, 2000.

Rao, C. R. N. and Chen, J.: Revised post-launch calibration of the visible and near-infrared channels of the advanced very high resolution radiometer (AVHRR) on the NOAA 14 spacecraft, Int. J. Remote Sens., 20(18), 3485-3491, 1999.

Ross, J.: The radiation regime and architecture of plant stands, Boston' Junk, 381 pp., 1981.

Schulla, J.: Hydrologische Modellierung von Flussgebieten zur Abschaänderungen, Ph.D. thesis, ETH Zurich, No. 12018, 1997.
Scurlock, J. M. O., Asner, G. P., and Gower, S. T.: Worldwide Historical Estimates of Leaf Area Index, 1932-2000, Oak Ridge National Laboratory, US Department of Energy (DE-AC0500OR22725), 2001.

Sellers, P. J.: Canopy reflectance, photosynthesis, and transpiration, Int. J. Remote Sens., 6, 1335-1372, 1985.

Sheikh, V., Visser, S., and Stroosnijder, L.: A simple model to predict soil moisture: Bridging Event and Continuous Hydrological (BEACH) modelling, Environ. Modell. Softw., 24(4), 542-556, 2009.

Simoniello, T., Lanfredi, M., Liberti, M., Coppola, R., and Macchiato, M.: Estimation of vegetation cover resilience from satellite time series, Hydrol. Earth Syst. Sci., 12, 1053-1064, 2008, http://www.hydrol-earth-syst-sci.net/12/1053/2008/.

Sivapalan, M., Beven, K. J., and Wood, E. F.: On hydrological similarity 2. A scaled model of storm runoff production, Water Resour. Res., 23, 2266-2278, 1987.

Vita, M., Cavuoti, C.,and Pagliaro, S.: Variazioni del ciclo idrologico nel bacino del fiume noce ed effetti sul litorale della piana di castrocucco (versante Tirrennico della Basilicata). Progetto MEDDMAN, Proceedings of "Convegno Nazionale di Maratea" antitled Coste Prevenire, Programmare, Pianificare, n. 9, May 2008.

Wu, J., Wang, D., and Bauer, M. E.: Assessing broadband vegetation indices and QuickBird data in estimating leaf area index of corn and potato canopies, Field Crop. Res., 102, 33-42, 2007.

Zierl, B.: A water balance model to simulate drought in forested ecosystems and its application to the entire forested area in Switzerland, J. Hydrol., 242, 115-136, 2001. 